\title{
防污効力の生物検定に関する研究-II 胞子の忌避反庀
}

\author{
宮内 徹 夫* \\ (昭和 55 年 8 月 27 日受理)
}

\section{Laboratory Methods for the Evaluation of Antifouling Paints and Toxic Chemicals II Avoidance Reaction of Swarm Spore of Enteromorpha compressa to Copper and Tin}

\author{
Tetuo MiYaUTI \\ Miyademy Fisheries Laboratory, Futami, Watarai.gun, Mie 519-06
}

(Received August 27, 1980)

前報（宮内，1980）の胞子テストを実施した際に，普 通海水中や低濃度の試験液中では，胞子は光を照射する 侧面か逆の側面に集まり，須藤（1950）のいう配偶子の 正の走光性, 接合子および遊走子の弱い負の走光性とい ら行動が明確に認められたのに対し, 高濃度の試験液中 での胞子には，その如き行動は認められなかった。

そこで，この胞子の光に対する行動について種々検討 してみた。その結果, 胞子に忌避反応と呼んでもよいよ らに判断される行動を喼めるとともに，その行動に防污 効力恰定法として利用し得る可能性を認めたので, ここ に報告する。

本文に先だち，本研究に際し指導と助言を賜わった三 重大学水産学部喜田和四郎教授ならびに供試海水の提供 をらけたカナエ塗料株式会社技術部高橋一啺氏に深謝の 意を表する。

\section{材料と方法}

供試液としては, $\mathrm{Cu} 0.30 \mathrm{ppm}, 1.90 \mathrm{ppm}, \mathrm{Sn} 0.41$ $\mathrm{ppm}, 1.91 \mathrm{ppm}$ と溶解濃度が明確な海水を, 供試胞子 としては, 三重県五十鈴川河口域にて採集したヒラアオ ノリEnteromorpha compressa から得た胞子を用いた。 前報（宮内，1980）の胞子テストで使用した透明アク リル板で作製した容器を用い，その仕切内に，10〜20\%

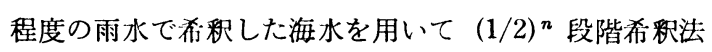
で希釈した 9 種類の陚験液と対照として雨水で希釈した 海水をそれぞれ $180 \mathrm{cc}$ 収容し,さらに, 別に準備した 胞子海水をそれぞれの仕切内の底に，ピペットを用いて

* カナ付着生物研究所・水产開発研究所
$20 \mathrm{cc}$ づつ静かに注入した。

この上うに，10２0\%程度の雨水で希釈した海水を用 いて希釈した試験液の底に, 雨水で希釈していない胞子 海水を静かに注入すると, 胞子海水は試験液とほとんど 混合することなく試験液の底にもぐり込み, 側面からみ ると，胞子で色づいた胞子海水と試験液とは層をなしは っきり区分されている。

そして, 以上の如く準備した谷器に, 胞子が正の走光 性を示す時には容器の上面より, 負の走光性を示す時に は容器の底面より, それぞれの光を照射して, 胞子の行 動を容器の側面から観察し記録した。

\section{結果}

光を照射すると, 対照海水や低濃度試験液の場合に は，胞子は活発にその中を移動し数分間で水面に集まる が, 高濃度試験液の場合には, 胞子そのものは胞子海水 中で活発に運動しているものの試験液中へは移動せず底 で層をなしており，その中間濃度では，一部の胞子は水 面に達するが，一部は底層や試験液中にとどまるという 現象がみられた。

胞子海水注入後 30 分の状態の代表例を四示すると, 四1のとおりである。

図にもみられる如く, 中間型のものは2 3 種類に分 類することも出来るが, ここでは便宣的に, 刘照海水の 場合と同様に表面に胞子が集まる場合を十，底買の胞子 游水中にそのままとどまる場合を一，中間型の場合を士 といら三つのタイプに大別し，観察の結果をとりまとめ ると, 表1のとおりになる。すなわち, 装にみられる如 


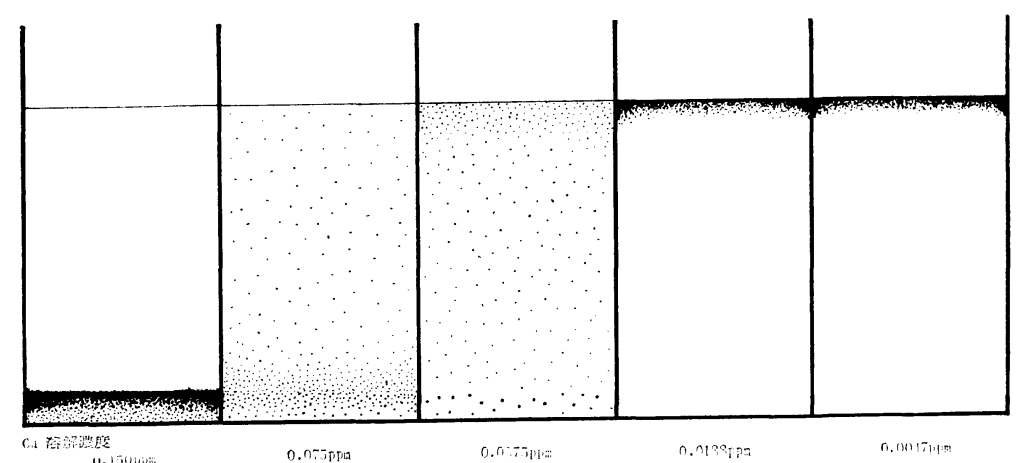

図 1. $\mathrm{Cu}$ 含有海水中でのヒラアオノリ胞子の行動（底闻より光を照射した，胞子の走光性は負）.

表 1. ヒラアオノリ胞子が $\mathrm{Cu}, \mathrm{Sn}$ 含有海水に示す忌避反応（符号の説明は本文参照）

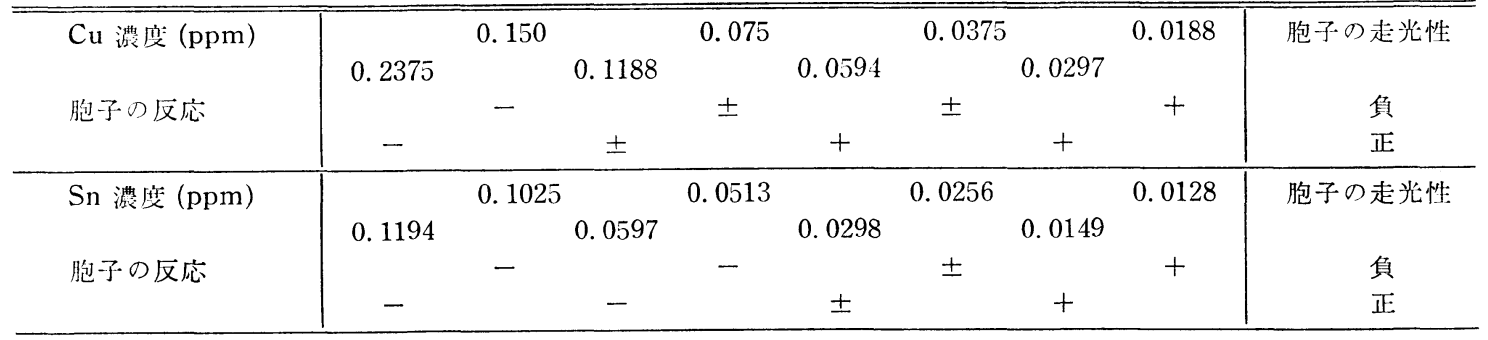

(実験月日：上段 6 月 17 日，下段 7 月 10 日。 1980 年)

く, 胞了は, $\mathrm{Cu}$ で $0.03 \mathrm{ppm}$ 程度, $\mathrm{Sn}$ では $0.015 \mathrm{ppm}$ 程度以下の濃度では, 普通海水の場合と間様に試騟液中 を移動し水面に集まるのに対し， $\mathrm{Cu}$ で $0.15 \mathrm{ppm}$ 程 度, $\mathrm{Sn}$ では $0.05 \mathrm{ppm}$ 程度以上の濃度になると試験液 中に移妫し得ず，注入した時の状態のまま底尿にとどま ることが観察された。

\section{考察}

前報（宮内，1980）の胞子テストを実施した際に，試 験液の希釈度の差により胞子の行動に相違のあることに 気付いてから，上述のごとき実験方法を究明するまでに かなりの日数を要し，本実験は 2 回行なっただけである が，それまでに実施した一連の予備実験においても高濃 度の試験液にて光に対する無反応という胞子の行動を認 めたことから，本実験でみた胞子の反応が例外的な特異 現象ということはまず考えられない。また，試験液中に 移動しないで底層にとどまっている胞子を検鏡してみる と，活発に運動しているだけに，胞子が光に反応し移動 して試験液と接触し死減したためにもたらされた現象と いらことも考えられなかった。

ところで，このよらに胞子がある程度以上の試験液中
へ移動しないといら行動を“忌避父応”と呼んでよいも のかぞらか。

ヒラアオノリなどの胞子に忌避应がみられるという ことについては，筆者の知るかぎりにおいては過去に解 告はない。また，カイコにて，食物中に含まれる“末知 の物質”によって，食物中に“視物質に関与する物与質” が久除することによって, さらにはクワ葉から発散され る“ある種の芳香”によって，その走光性行動が抑兄ら れ消失されることが知られている（清水，1977; 哖水・ 加藤，1978）ことからすれば，本实験の結果についても も, 胞子が $\mathrm{Cu}, \mathrm{Sn}$ を忌避するのではなく, ある濃度以 上の $\mathrm{Cu}, \mathrm{Sn}$ に胞子の走光性行動を抑える作用があり, その結果もたらされた現象と解釈することも可能である ら。それだけに，本実験の結果のみから，これを忌避义 応と呼ぶのは多少大胆すぎるかもしれないが，一応ここ では，上記の如き走光性行動を抑え消失させる作用によ る現象も含め, 本実験でみられた如き反応を“胞子の忌 避反応”と呼ぶことにする。

ただ，海中での胞子の移動は多くの場合全く他動的に 海水の流動によって行なわれる（鿓藤，1950）と考えら れるだけに，胞子が示すこの忌避反応が実際の海でもみ 
られるかといら点になると,かなり疑問が生じる。少な くとも, 防污塗料の浸漬実験では, 防藻効果は, 胞子の 付着を阻止した結果（胞子が忌避し付着しなかった結 果）というよりも，付着した胞子が死隇した結果もたら されたと考えたずが理解しやすい例が多い。いずれにし ても，今回認めたこの胞子の忌避反応については，今後 さらに検討し，後日あらためて論議することにする。

一方，本実験でみた胞子の忌避反応を防活効力の生物 梌定法として利用出来始かという点について考えてみる

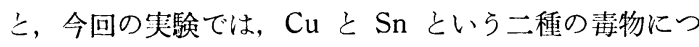
いてみたのみであるし, 走光性が正の胞子と負の胞子と では忌避反応を示す $\mathrm{Cu}$ の濃度に多少差が認められるな ど，今後さらに検討しなけ㞦ばなら課題を残すし，ま た，忌避反応を示す生物について総ての種類の薬品等を 忌避するわけでない（松江，1961）ことが知られている ことからも，現在これを直ちに防污効力の生物検定法之 して広く採用するには問题があるとい方る。ただ，Cu とSnについていえば, 胞子が進入し得ない試験液の濃 度は，前㪕（宮内，1980）の結果との比較からも明らか な如く, 防藻有効濃度内に含まれているだけに，少なく とも $\mathrm{Cu}$ やn を含む防污叙料などの防藻効力の有無や 強弱をスクリーニングする方法としては充分に有効であ る。特に, 垁験開始後 30 分程度で判定出来るといら仵 れた長所を有するだけに，その価值は高いといえよう。

いずれにしても，この胞子の忌避反応については，今 後さらに多方面から検討すべきであり，また，検討する 佃值は充分にあるといらことが，本実験により明らかと
なったといえる。

要約

1. ヒラアオノリの胞子に忌避反応を染めた。

2. ヒラアオノリの胞子は, $\mathrm{Cu} 0.15 \mathrm{ppm}$ 程度以上, Sn $0.05 \mathrm{ppm}$ 程度以上の溶解濃度の海水を忌避した。

3. ヒラアオノリの胞子が示す忌避反応を防藻効力の 生物検定法として広く採用するまでには，さらに検討す ベき裸題を多く残すが，少なくとも Cu か $\mathrm{Sn}$ を含有す る防励塗料などの防藻効力の有無や強弱を判定するスク リーニング法としては有効と判断した。

4. 短時間で結果が出せるだけに, 防藻效力のの生物㭘 定法として，今後さらに検討すべき洒值を们すると判断 した。

\section{文献}

加藤腾 (1979). 光とカイコ.「光生物登〈下〉, 柴四・ 佐原・宮地編， $290+x$ xiii，学会出版七ンタ一，東 京」 153-163.

松江吉行編 (1961)。污濁の概要.「公共用水域保企の ための水質污濁調查指針，384+10。憬星社厚生閣， 東京」2-31.

宫内徽夫 (1980)。防污効力の生物検定に関寸る研究 -I. 咆子テストと葉片テスト. 付着生物研究, 2(1), $1-4$.

須藤俊造 (1950)。海藻の胞子の放出・散布及び着生 に關する研究. 海藻胞子付けの研究第 8 報. 日水 彭: $16(1), 1-9$. 